\title{
維持透析患者における副甲状腺摘除術の 腎性貧血に及ぼす影響
}

\author{
吉田克法鳥本一匡* 壬生寿一* 谷善 啓* \\ 中辻史好* 田中正已* 高尾雅也* 影林 頼明* \\ 大園 誠一郎* 岡島 英五郎* 平 尾 佳 彦* \\ 奈良県立医科大学附属病院透析部 奈良県立医科大学泌尿器科学教室*
}

key words：腎性貧血, 副甲状腺ホルモン, 副甲状腺摘除術, エリスロポエチン

〈要旨〉

背景と目的：維持透析患者に認められる腎性賓血の原因は，造血ホルモンであるエリスロポエチン（EPO）の相 対的低下が主な原因であるが, 透析患者に特有な血中尿毒症性物質も重要な因子とされている。今回, 手術を必要 とする二次性副甲状腺機能元進症症例に副甲状腺全摘除術後自家移植術（PTx）を施行した症例についてPTxの賓 血に及ぼす影響を検討した。

対象と方法：二次性副甲状腺機能元進症を合併した維持透析患者 11 例について PTx 後の血清副甲状腺ホルモン (高感度 PTH：HS-PTH，C末端PTH：C-PTH, intact-PTH) 值, 貟血指標としての赤血球 (RBC) 值, 血中へモ グロビン $(\mathrm{Hb})$ 值, 網状赤血球数, さらに血中 EPO 濃度を経時的に観察し, さらに EPO 製剤の投与量の変化と EPO 製剂への感受性についても検討した。

結果：11 例全ての症例でPTx 後に血清 C-PTH 值, HS-PTH 值, および intact-PTH 值は著しい低下を示し, こ れに伴い RBC 值, $\mathrm{Hb}$ 值, 網状赤血球数は上昇を示した。経過観察中において血清 $\mathrm{EPO}$ 值は変化が認められなかっ たが，大部分の症例で EPO 製剤の投与量は減少し，EPO 製剤に対する感受性が増大したことを示した。

結論：EPO 製剤にて反応性の低い維持透析患者の腎性賓血に対し，PTxが有効であると考えられた。

\section{Role of parathyroidectomy on erythropoiesis in maintenance hemodia- lysis patients}

Katsunori Yoshida, Kazumasa Torimoto*, Toshikazu Mibu*, Yoshihiro Tani*, Fumiyoshi Nakatsuji*, Masaki Tanaka*, Masaya Takao*, Yoriaki Kagebayashi*, Seiichirou Ozono*, Eigoro Okajima*, Yoshihiko Hirao*

Division of Hemodialysis, Nara Medical University Hospital ; Department of Urology, Nara Medical University*

Background: Anemia is common in patients with chronic renal failure (CRF) receiving maintenance hemodialysis (HD). Relatively decreased production of erythropoietin (EPO) is the main factor underlying the anemia in these patients. However, this concept does not always account for the anemia and other mechanisms of EPO activity inhibition such as uremic toxins may also play a role. Uremic toxin accumulates in hemodialysis patients, and parathyroid hormone (PTH) may be a uremic toxin. In this study, the effect of PTH on anemia of patients with CRF receiving HD was evaluated after total parathyroidectomy (PTX) with autotransplantation.

Material and method: PTx was performed in 11 hemodialysis patients with secondary hyperparathyroidism and anemia. Serum HS-PTH, C-PTH and intact-PTH were evaluated chronologically after PTx, and the RBC level, $\mathrm{Hb}$ level, and reticulocyte counts were evaluated as erythropoiesis in the same period. In addition, serum EPO levels were estimated between pre-PTx and the final evaluation of this study, defined as post-PTx.

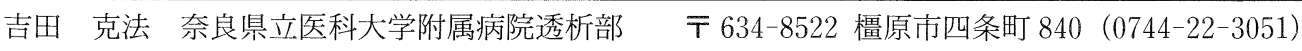

Katsunori Yoshida Fax 0744-22-9282

〔受付：平成 10 年 3 月 18 日, 受理 : 平成 10 年 10 月 7 日〕 
Result : The levels of serum HS-PTH, C-PTH, and intact-PTH decreased immediately after PTx. On the other hand, RBC, $\mathrm{Hb}$ and reticulocyte counts decreased temporarily after PTx, but increased gradually from 1 to 2 months after PTx. Concerning serum EPO, the levels did not change significantly between pre-PTx and postPTx, and the dose of recombinant human EPO ( $r$-hEPO) agent significantly decreased.

Conclusion: These findings demonstrated that elevated PTH affected erythropoiesis in CRF patients with HD, and suggested that parathyroidectomy is useful for anemia if adequate doses of $r-h E P O$ are not effective in HD patients.

\section{緒言}

腎性貧血抢よび二次性副甲状腺機能立進症は維持透 析患者に認められる一般的な合併症である。前者は工 リスロポエチン (EPO) の相対的不足が主な原因とさ れており，現在では $\mathrm{EPO}$ 製剤の普及により多くの維 持透析患者がその恩恵に預かり，重篤な貧血に悩む症 例は減少してきた。しかし，相当量の EPO 製剤の投与 にもかかわらず，著しい貧血が持続する症例も少なか らず存在し, 造血抑制物質としての uremic toxinの関 与が示唆されている.

二次性副甲状腺機能元進症は，透析患者にみられる 腎性骨異栄養症（ROD）の最も重要な原因であり，著 しく上昇した副甲状腺ホルモン (PTH) は，骨に対し ては線維性骨炎を主とした変化を引き起こし，骨髄の 広汎な線維化の原因となっている。ささに PTH は直 接的な赤血球産生障害, 赤血球寿命の短縮等に関わる uremic toxinの一つとされている。今回，我々は骨関 節障害を主とした二次性副甲状腺機能立進症症例に対 し副甲状腺全摘除術後自家移植（PTx）を施行した症 例に関して，PTHの貧血に及ぼす影響および EPO 製 剤の感受性の変化について検討した。

\section{I 、対象および方法}

対象症例は慢性系球体腎炎を原因疾患とした維持透 析患者(男性 6 例，女性 5 例)，年齢は 37 歳より 64 歳 で透析歴は 65 か月より 215 か月の長期透析患者であ る。主訴は骨関節症状を主とし，二次性副甲状腺機能 亢進症と診断され, ビタミン $\mathrm{D}_{3}$ 間歇大量療法 (パルス 療法）の保存的治療にても効果が認められず，手術目 的で入院した症例である。血清 HS-PTH は 32000 $\mathrm{pg} / \mathrm{m} l$ より $230000 \mathrm{pg} / \mathrm{m} l$ と著しい高值を示してお り,また血清 C-PTH, intact-PTH も同様に高值を示 していた。また頸部超音波検査等の画像診断でほとん どの症例が副甲状腺 4 腺腫大が認められていた。

貧血に関しては，長期にわたり $\mathrm{EPO}$ 製剤を投与さ れ, $\mathrm{RBC}$ は $194 \times 10^{4} / \mu l$ より $493 \times 10^{4} / \mu l$ であり, 症
表 Characteristics of hemodialysis patients and HS-PTH \& RBC level

\begin{tabular}{rccccccc}
\hline Case & Sex & Age & $\begin{array}{c}\text { Duration of } \\
\text { HD (mo.) }\end{array}$ & $\begin{array}{r}\text { HS-PTH } \\
(\mathrm{pg} / \mathrm{ml})\end{array}$ & $\begin{array}{c}\text { RBC } \\
\left(\times 10^{4} / \mu \mathrm{l}\right)\end{array}$ & $\begin{array}{l}\text { Follow up } \\
\text { periods (mo.) }\end{array}$ \\
\hline 1. & $(\bullet)$ & $\mathrm{M}$ & 46 & 130 & 130000 & 194 & 36 \\
2. & $(-)$ & $\mathrm{M}$ & 62 & 120 & 50000 & 289 & 12 \\
3. & $(\Delta)$ & $\mathrm{F}$ & 49 & 147 & 64000 & 337 & 12 \\
4. & $(\times)$ & $\mathrm{M}$ & 45 & 215 & 80000 & 493 & 12 \\
5. & $(*)$ & $\mathrm{M}$ & 43 & 192 & 49000 & 285 & 18 \\
6. & $(\bullet)$ & $\mathrm{M}$ & 38 & 207 & 230000 & 190 & 18 \\
7. & $(+)$ & $\mathrm{M}$ & 51 & 198 & 72000 & 285 & 6 \\
8. & $(-)$ & $\mathrm{F}$ & 64 & 144 & 37000 & 235 & 12 \\
9. & $(-)$ & $\mathrm{F}$ & 45 & 128 & 150000 & 301 & 3 \\
10. & $(\bullet)$ & $\mathrm{F}$ & 48 & 168 & 32000 & 345 & 6 \\
11. & $(\square)$ & $\mathrm{F}$ & 37 & 65 & 110000 & 284 & 12 \\
\hline
\end{tabular}

例 4 を除いて EPO 製剤を必要とする腎性貧血を示し ていた（表）.

手術法は全身麻酔下に副甲状腺 4 腺を全て摘除し, その一部を前腕に自家移植する方法を原則とした1). 術後の低 Ca 血症に対しては, 術直後より経時的にイ オン化 $\mathrm{Ca}$ 值を測定し, $\mathrm{Ca}$ 製剤を適宜静脈投与し, $\mathrm{Ca}$ 濃度が安定した時点で少量のビタミン $\mathrm{D}_{3}$ 製剂および $\mathrm{Ca}$ 製剂の経口投与に切り替え維持投与量とした。 PTx 前およびPTx 後に血清 HS-PTH，C-PTH， intact-PTH 濃度を経時的に測定し，また骨吸収を反 映する血清アルカリフォスファターゼ $(\mathrm{Al}-\mathrm{p})$ を $\mathrm{PTx}$ 前と PTx 後の最終観察時期に比較検討し, PTx の効 果および骨に対する変化を評価した。また赤血球 $(\mathrm{RBC})$, 血中へモグロビン $(\mathrm{Hb})$, 網状赤血球数 (reticulocyte) を測定し, PTx 後の血清 PTH の変化 と貧血状態の変化を経時的に検討した. $\mathrm{EPO}$ 製剤投与 量および血清 $\mathrm{EPO}$ 濃度に関してはPTx 前とPTx 後 の最終観察時期で比較検討した。また EPO 製剤に対 する感受性の指標として網状赤血球数/EPO 製剤投与 量を PTx 前および PTx 後の最終観察時期で評価し た. 血清 HS-PTH, C-PTH, intact-PTH, 血清 EPO 濃度は radioimmunoassay 2 抗体法で測定し，採血時 期は透析開始時とした。

\section{II. 結 果}

PTx における術中の出血はほとんど認めず, 輸血を 


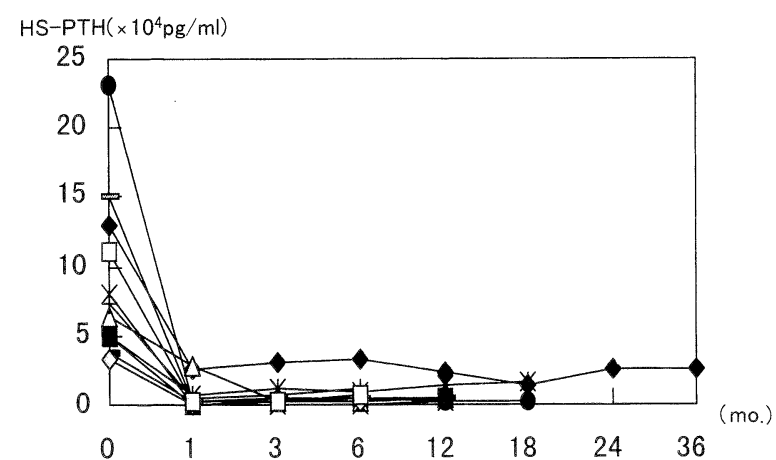

図 1 Chronological changes of HS-PTH level post PTx

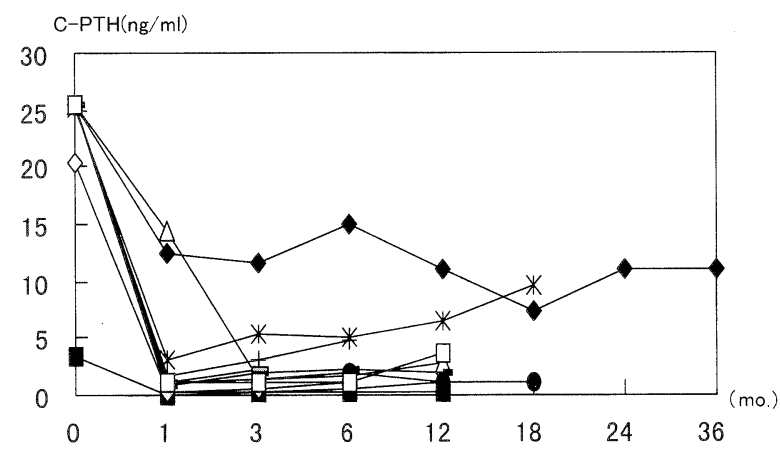

図 2 Chronological changes of C-PTH post PTX

必要とした症例はなかった.PTx 後の観察期間は 3 か 月より 36 か月であった。 PTx 後の血清 PTH 濃度は HS-PTH, C-PTH および intact-PTH の 3 測定法に おいて, 術後より1か月目にかけて全ての症例で速や かな低下を示し, 特に血清 HS-PTH 濃度はPTx 術 直後より著しい低下を示した。自家移植した副甲状腺 片の機能は, PTx 術後 6 か月目頃より徐々に回復し, PTH の再上昇が認められ, C-PTH でその傾向が著し かった(図 1，2，3）。血清 Al一p 值は PTx 後に低下し た症例がほとんどで, 特に PTx 前に高值を示した症 例においてその傾向が著しかった（図 4 ）。

術後の貧血の経時的な変化については, 術後 1 か月 目にほとんどの症例で一過性の $\mathrm{RBC}, \mathrm{Hb}$, 網状赤血球 数の低下を認めたが, 術後 3 か月目より上昇が認めら れた。これらの症例のうち, 症例 1,602 症例におい て 6 か月目と 12 か月目に RBCの一時的な低下がみ られたが，これらの症例は同時期に $\mathrm{EPO}$ 製剤投与量 を減量した症例である（図 5，6，7）。

PTx 術前後の血漿 EPO 濃度の変化については, PTx 前值と最終観察日の血清 $\mathrm{EPO}$ 濃度を PTx 後值 として比較検討したが, 血清 EPO 濃度は術前後で有 意な差は認めなかった(図 8 )。EPO 製剤の投与量に関 し, PTx 術後に EPO 製剤の減量可能であった症例は

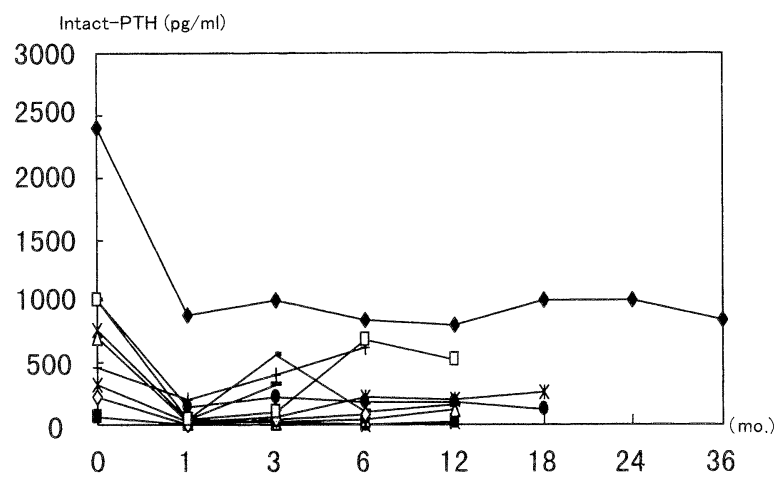

図 3 Chronological changes of intact-PTH post PTx

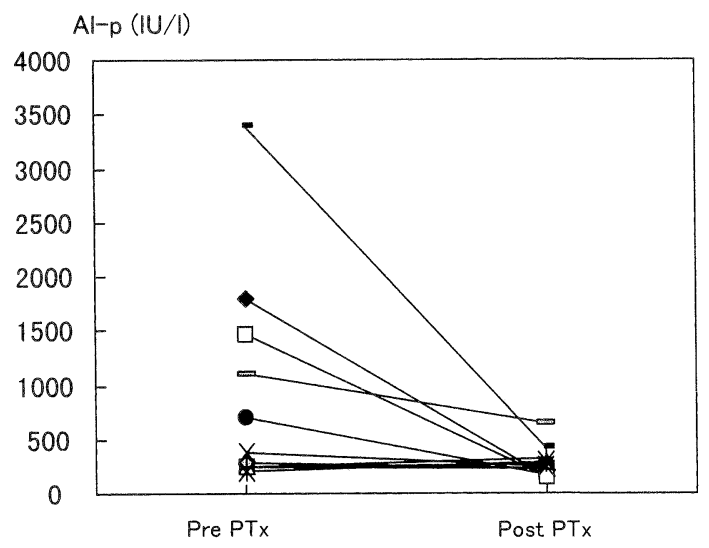

図 4 Changes of Al-p between pre \& post PTx

11 例中 8 症例 (72.7\%) で, そのうち週 9000 単位, 4500 単位を使用していた 2 症例で, PTx 後には EPO 製剤 を必要としない症例も認めた. 3 症例は $\mathrm{EPO}$ 製剤投与 量には変化は認められなかったが，同投与量で貧血状 態は改善傾向を示した(図 9 )。EPO 製剤に対する感受 性の指標としての網状赤血球数/EPO 製剂投与量は, $\mathrm{PTx}$ 後に EPO 製剂の投与の不必要になった症例も 含めて, PTx 後は PTx 前に比較して高值を示した (図 10).

\section{III. 考 察}

末期腎不全症例, 特に維持透析症例における合併症 のうち腎性貧血は患者の QOL に大きな影響を及ぼす 重要な合併症であったが, EPO 製剤の登場により輸血 を必要とするような著しい貧血症例はほとんど認める ことはなくなった。しかし，EPO製剤の多量投与に よっても貧血の改善がみられない症例も少なからず認 められており, 原因として鉄・葉酸の欠乏, 感染症あ るいは炎症性疾患, 高アルミニウム血症, 骨髄線維化, 透析による残血, さらに種々の造血阻害物質の存在が 


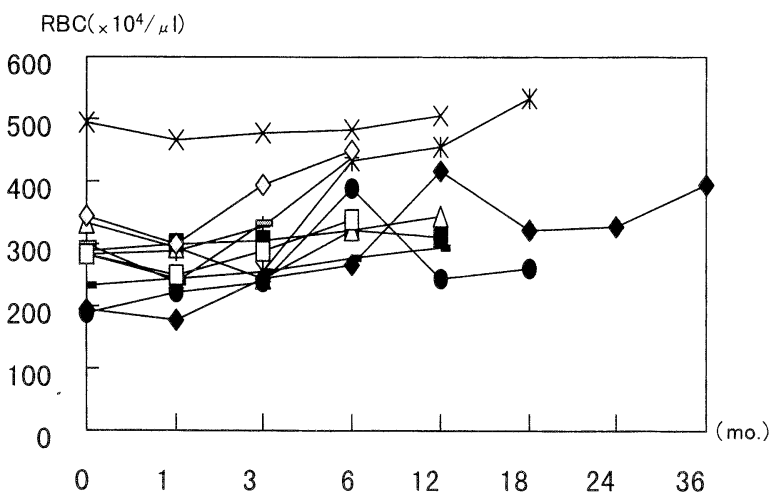

図 5 Chronological changes of RBC post PTx

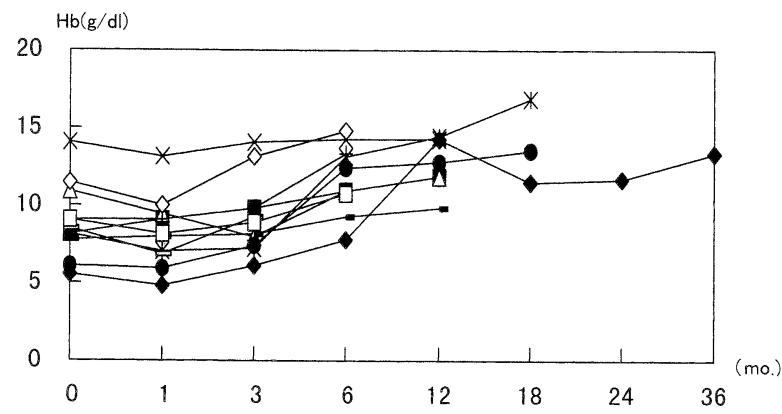

図 6 Chronological changes of $\mathrm{Hb}$ post PTx

reticulocyte count $\left(/ \mathrm{mm}^{3}\right)$

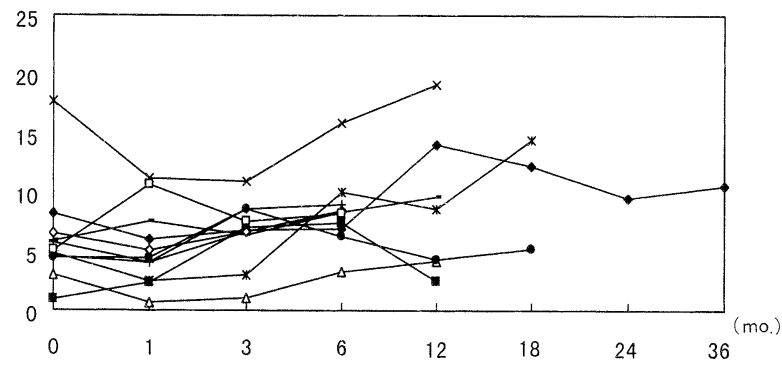

図 7 Chronological changes of reticulocyte counts post PTx

指摘されている2). 透析患者の血中 EPO 濃度の測定に 関しては radioimmunoassay (RIA) 法にて測定されて いるが, 維持透析患者の血中 EPO 濃度は健常者の血 清 $\mathrm{EPO}$ 濃度と比較しても，有意な低下を認められて おらず3)，貧血が存在するにもかかわらず，血清 $\mathrm{EPO}$ 濃度が高值の症例も存在している。一方, EPOの生物 学的活性に関しては, 種々の方法により測定した報 告 ${ }^{4)}$ がみられるが，著者らは以前に fetal mouse liver cell を用いた in vitro colony forming unit of erythroid assayにより維持透析患者および健常者の EPO 活性を測定し報告した。その結果, 維持透析患者の生 物学的 EPO 活性は健常者に比較して有意な低下を示 していたが3), RIA 法における血清 EPO 濃度は低值を

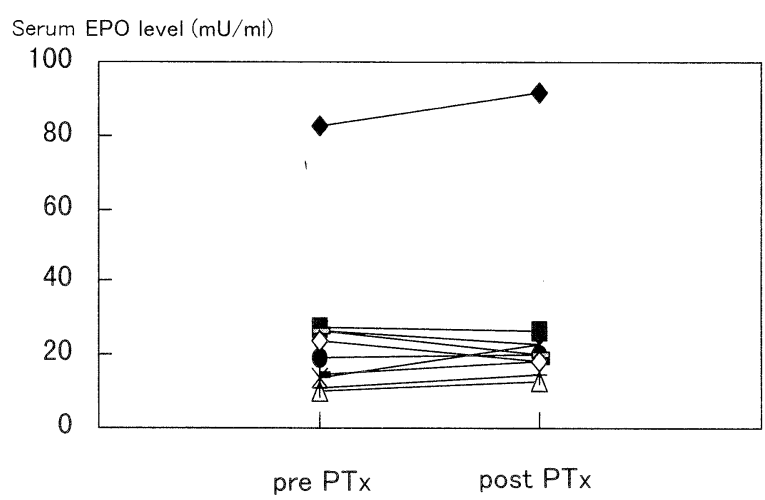

図 8 Changes of plasma EPO levels between pre \& post PTx

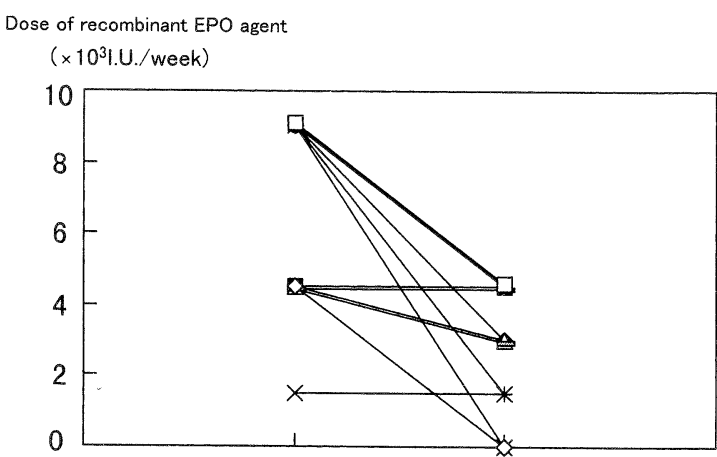

pre PTx post PTx

図 9 Changes of dosage of recombinant-EPO agent between pre \& post PTx

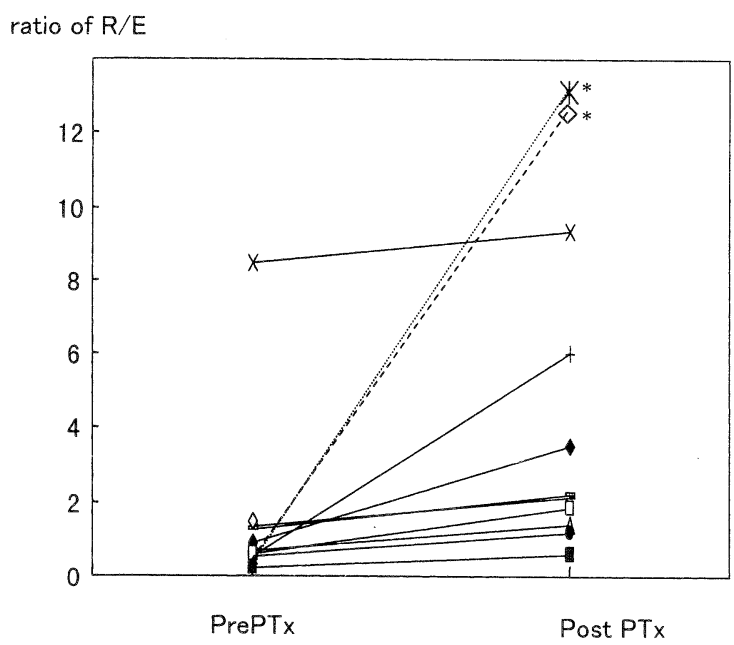

図 10 Changes of ratio of reticulocyte counts/ $\mathrm{r}$-EPO dose $(\mathrm{R} / \mathrm{E})$ between pre \& post PTX

(* case 5 . case $10:$ non-treatment by r-EPO at post PTx)

示していないことより, 慢性腎不全患者においては造 血抑制物質の存在が示唆されている5). 今回, RIA 法に て測定した血清 EPO 濃度に関し検討した 9 症例にお 
いても 1 例を除いて, 血清 EPO 濃度は PTx 前および 最終観察期において有意な差を認めず, PTx 後の貧血 の改善は血中 $\mathrm{EPO}$ 濃度の変化のみに起因するもので はないことが推察された。

副甲状腺ホルモン (PTH) は，保存期の腎不全の病 態においても腎性貧血の発現とともに上昇傾向が認め られ，さらに末期腎不全状態となり維持透析療法が長 期に及ぶとさらに血清 PTH 濃度は上昇傾向を示し, 骨関節症状を中心とした二次性副甲状腺機能進症が 発現する。長期にわたる PTH の著しい上昇は骨髄の 線維化を引き起こし，骨髄の造血部位の線維化により 造血機能が低下し, 維持透析患者における貧血が一段 と助長される。我々の症例においても, 血清 $\mathrm{A} 1-\mathrm{p}$ 值が $\mathrm{PTx}$ 後に減少を示し, 同時に貧血の改善が認められた ことは，六進していた骨吸収が改善されることにより 造血部位としての骨髄機能の改善が得られることが推 測された。 Quarles ら ${ }^{6}$ は末期腎不全患者 39 例に対し て骨生検を施行し, PTH 濃度が著しく高い症例は, 骨 髄部位の線維化が著明で，これらの症例においては血 清 PTH 值と骨髄線維化の程度は相関することを報告 し，透析患者において PTH は骨髄造血部位の線維化 および骨吸収により間接的に造血抑制に関わっている ことを示唆している.PTHの直接的な造血抑制作用 については, Meytes らはPTH の erythropoiesisに 対する直接的影響を検討するために, mouse bone marrowを使用して bone marrow erythroid colonyforming unit (CFU-E) による生物学的活性を測定し, PTH 自体が造血抑制因子であることを報告してい る。我々の症例のうち, 症例 1 および症例 6 は血清 PTH が著しく高值を示し，PTx 後の貧血改善の程度 が速やかである点から，PTxの直接的な造血抑制作 用, あるいは赤血球寿命に対して直接的増悪因子とし て機能していることが推察された。

一方, 臨床的に Algilés ら ${ }^{8}$ は血清 intact-PTH が $500 \mathrm{pg} / \mathrm{m} l$ 以上を示している維持透析患者に alfacalcidol の大量間歇療法を施行し, 血清 intact-PTH が 低下するとともに貧血が改善することを報告してい る.しかし今回対象とした症例においては, PTx 前に 二次性副甲状腺機能六進症の治療目的で alfacalcidol あるいは calcitriol の大量間歇療法 (パルス療法)を施 行しているが，貧血状態の改善は得られておらず，貧 血に対するパルス療法の有用性にはさらに検討が必要 である。

PTx 後の血清 EPO 濃度に関しては，今回の我々の 検討では PTx 前後で，EPO 製剤を減量したにもかか わらず有意な差を認めなかったが, Urena ら
後の血中 EPO 濃度 (RIA 法) は上昇し, 貧血は改善し たと報告している。またRaoら ${ }^{10)}$ はbone marrow fibrosis と血清 PTH 濃度の有意の相関を確認した上 で，血中 EPO 濃度と bone marrow fibrosis の程度は 有意な相関が認められるとし, EPO 製剤による貧血改 善効果の認められない症例に対する PTx の有用性を 示唆している.しかし, 我々の症例においてはPTx 前 および最終観察期で血清 EPO 濃度に有意な変化は認 められず，特に症例 1 においては血清 EPO 濃度は著 しい高值を示しているにもかかわらず，貧血の程度は 逆に著しく, EPO の効果発現に関して PTH の直接的 要因も考えられた. $\mathrm{EPO}$ 投与量の減量にもかかわらず 血清 $\mathrm{EPO}$ 濃度の低下が認められなかった理由とし て, 前述したごとく RIA 法にて測定した透析患者の血 清 $\mathrm{EPO}$ 濃度は健常者とほとんど差がなく, in vitro bioassay (CFUE) の検討で透析患者は低下を示したこ とより，腎不全患者においては，蓄積された生物学的 活性を示さないEPO like substance が多量に存在し, 血清 EPO 值 (RIA 法) が低下を示さなかったものと推 察された。

$\mathrm{PTx}$ 後の $\mathrm{EPO}$ 製剤の投与量に関しては, 貧血の改 善に伴い $\mathrm{EPO}$ 製剤の投与量は 8 例で減量が可能であ り，3 例で PTx 前投与量を継続し, 投与量の増加を必 要とした症例はなかった. PTx 前投与量継続の 3 例に おいても，へマトクリット值は $28 \%$ 以上と徐々に上昇 傾向にあり，投与量の漸減予定である。血清鉄に関し

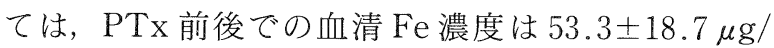
$\mathrm{d} l, 59.5 \pm 22.5 \mu \mathrm{g} / \mathrm{d} l$ とほとんど変化は認めず，また $\mathrm{PTx}$ 前より鉄剂を投与していた症例は 1 例のみで あった。

$\mathrm{PTx}$ 後 1 2 2 少間における一時的な貧血の増悪傾 向については，手術による影響あるいはPTx 後の持 続的な低 $\mathrm{Ca}$ 状態が $\mathrm{EPO}$ 効果発現において抑制的に 機能している可能性がある ${ }^{11)}$. 重松ら ${ }^{12)}$ も PTx 後に一 時的な貧血の増悪の後に貧血の改善を確認しており, その機序として EPO 製凨の感受性の増加, PTH 除去 による骨髄機能の改善, 赤血球寿命の改善を指摘して いる。我々の症例に扔いては, PTx 後約 2 か月目より 貧血状態が改善し, さらに 11 例中 8 例で $\mathrm{EPO}$ 製剤の 減量が可能であったが, 貧血改善の機序としては, PTH の造血作用に関する直接的な抑制作用， あるい は赤血球に対する直接的な作用も考えられた。特に血 清 PTH 濃度の著しく高值を示す症例において，PTx 後に速やかに改善したことは, 赤血球および造血に対 する直接的作用の存在が示唆された。 しかし, 今回経 験した全症例を通じて，貧血は PTx 後 $2 \sim 3$ か月目よ 
り改善傾向を示したことより, PTHの低下による bone marrow の造血機能発現までには一定の時間が 必要であったと推察された。

QOL の面からみると, PTx 後は骨関節症状が改善 され，また貧血の改善とともに活動範囲も拡大される ことにより食餌摂取量も増加し, PTx 後の血清蛋白濃 度も上昇していることから判断しても, これらの要因 が益々貧血改善に相乗効果を示したものと思われた。

以上今回の研究に扔いて，PTxに上り EPO 抵抗性 の腎性貧血の改善がみられることを示したが，さらに 従来より指摘されている PTH 自体にも造血抑制作用 を有することが確認でき, $\mathrm{EPO}$ 製剤投与にても貧血改 善のみられない維持透析症例には, PTx は選択すべき または考慮すべき治療法の 1 つであることが示唆され た。

\section{文献}

1) Bessell JR, Proudman WD, Parkyn RF, Disney APS : Parathyroidectomy in the treatment of patients with chronic renal failure: a 10-year review. Br J Surg 80:40-42, 1993

2) Van Wyck DB, Stivelman JC, Ruiz J, Kirlin LF, Katz MA, Ogden DA : Iron status in patients receiving erythropoietin for dialysis-associated anemia. Kidney Int $35: 712-716,1989$

3）吉田克法：維持透析患者におけるエリスロポエチン活 性一CFU-E 由来コロニー形成能と血漿 EPO 濃度の 比較一. 奈良医学雑誌 $41: 1-8,1990$

4) Wellner SF, Kurnick JE, Ward HP, Vautrin R, Alfrey AC : The anemia of chronic renal failure and chronic disease : In votro studies of erythropoiesis. Blood 47:561-569, 1976
5) Cassidy MJ, De Jager C, Ebrahim O, Camachio P, Robson S:Peripheral blood mononuclear cells from patients with chronic renal failure release factors which supprèss erythropoietin secretion in vitro. Nephrol Dial Transplant 9:775-779, 1994

6) Quarles LD, Lobaugh B, Murphy G : Intact parathyroid hormone overestimates the presence and severity of parathyroid-mediated osseous abnormalities in uremia. J Clin Endocrinol Metab 75: 145-150, 1992

7) Meytes D, Bogin E, Ma A, Dukes PP, Massay SG : Effects of parathyroid hormone on erythropiesis. J Clin Invest $67: 1263-1269,1981$

8) Algilés A, Mourad G, Lorho R, Kerr PG, Flavier JL, Canaud B, Mion M : Medical treatment of severe hyperparathyroidism and its influence on anaemia in end-stage renal failure. Nephrol Dial Transplant $9: 1809-1812,1994$

9) Urena P, Eckardt KU, Sarfati E, Zingraff J, Zins B, Roullet JB, Roland E, Drueke T, Kurtz A : Serum erythropoietin and erythropoiesis in primary and secondary hyperparathyroidism : effect of parathyroidectomy. Nephron $59: 384-393,1991$

10) Rao DS, Shin MS, Mohini R : Effect of serum parathyroid hormone and bone marrow fibrosis on the response to erythropoietin in uremia. N Engl J Med 328: 171-175, 1993

11) Scaro JL, Miranda C, Cardoso O, Martin B, Carrera MA : Acute hypocalcemia and erythropoiesis in the mouse. Acta Physiol Lat Am 30：125-131, 1980

12）重松 隆，前澤浩美，若林良則，百瀬光生，山本裕康, 久保 仁，川口良人，酒井 紀：長期血液透析患者に 打ける副甲状腺摘出術 (PTX) 前後における $\mathrm{rHuEpo}$ 治療効果の検討。透析会誌 $26: 1157-1163,1993$ 